\title{
An Analysis of Open Innovation Strategies in Firms in Low and Medium Technology Industries
}

\author{
María Luisa Flor ${ }^{\circledR}$, María J. Oltra-Mestre ${ }^{\circledR}$, and Elena L. Sanjurjo
}

\begin{abstract}
Open innovation (OI) has been mainly associated with high-technology firms. This paper aims to analyze how firms in low and medium technology industries implement their OI strategy. In doing so, we explore common patterns in OI strategies by considering inbound, outbound, and coupled OI practices. We also examine whether there are differences in innovation performance among companies adopting a specific OI strategy. The study is carried out on a sample of 242 Spanish innovating companies. Based on the relevance of the different $\mathrm{OI}$ practices, we identify three types of $\mathrm{OI}$ firms: advanced open innovators, intermediate open innovators, and incipient open innovators. Our results reveal that advanced open innovators have a higher performance in product innovation, and that there are no differences among groups in process and organizational innovation.
\end{abstract}

Index Terms-Coupled OI, inbound OI, low and medium technology industries, open innovation (OI) practices, outbound OI.

\section{INTRODUCTION}

$\mathbf{O}$ PEN innovation (OI) was initially associated with hightech contexts where technological breakthroughs are an important form of innovation and firms develop new business opportunities based on technology sourced from other organizations [1]. Although OI does accurately characterize innovation processes in these industries, they represent only a few of the many sectors in an advanced industrial economy, and evidence beyond its initial area of inquiry is essential to gain external validity as a new paradigm for industrial innovation [2]. This is the case of firms in low and medium technology (LMT) industries, whose economic importance and specific innovative ability has been overlooked by mainstream innovation research and innovation policy in many cases [3], [4]. While firms in LMT industries invest less in $\mathrm{R} \& \mathrm{D}$ and are less innovative than high-technology (HT) firms, they do, nevertheless, generate new products and

Manuscript received March 19, 2018; revised July 26, 2018, December 6, 2018, and February 27, 2019; accepted April 4, 2019. This work was supported by the Spanish Ministry of Science and Technology Project ECO2011-29201. The work of M. L. Flor was supported by the Spanish Ministry of Education Culture and Sport within the framework of its International Mobility Program for Senior Researchers "Salvador de Madariaga" (Reference PRX16-00476). Review of this manuscript was arranged by Department Editor D. Meissner. (Corresponding author: M. Luisa Flor.)

M. L. Flor and M. J. Oltra-Mestre are with the Department of Business Administration and Marketing, Universitat Jaume I, 12071 Castello de la Plana, Spain (e-mail: mflor@uji.es; oltra@uji.es).

E. L. Sanjurjo is with the Facultad de Ciencias, Universidad de Navarra, 31008 Pamplona, Spain (e-mail: esanjurjo@unav.es).

Digital Object Identifier 10.1109/TEM.2019.2911253 production processes that have a considerable aggregate impact in national economies [5].

Firms in LMT sectors have different objectives and face different challenges from their high-tech counterparts that will influence the innovation practices and strategies they develop [6]. Given their lack of R\&D resources, the innovation processes in LMT firms are characterized by being primarily based on practical, experience based, often implicit knowledge, and by integrating and adapting externally generated knowledge to their manufacturing processes, which helps explain the greater relevance of process innovations in this type of firm [3], [7]. Organizational innovations are also important in the LMT context, as they are often directly linked to technical innovation processes; in this regard, LMT firms do not differ from HT firms. In contrast, product innovation plays a far more limited role in LTM industries, which might be due to their lack of technologyoriented competencies and specialized R\&D capacities [3]. Hence, challenges, such as resource constraints or commoditized products, can act as drivers for LMT firms to search beyond organizational boundaries in their innovation activities [6].

Since OI can be a sensible strategy for managers in LMT contexts to boost their innovation efforts, it is important to systematically analyze how OI functions in such settings in order to enable them to take greater advantage of opportunities for OI [1]. This view had already been put forward by Chesbrough and Crowther [2, p. 230] more than a decade ago, when they stated "it remains an open question whether the concepts of OI apply to lower technology or more traditional industries." Nevertheless, since then, relatively few studies have explicitly focused on OI in firms in this type of industry (e.g., [6], [8]-[11]), which reinforces the need for further research in these settings.

The adoption of an OI strategy assumes that firms' innovation processes can be improved by purposively managing external knowledge inflows and internal knowledge outflows through inbound, outbound, and coupled types of OI [12]. The fact that external knowledge sources are relevant in LMT firms indicates that their innovation process has a certain openness of the inbound type. Less is known about which activities relating to knowledge outflows or coupled processes LMT firms adopt and how they relate to their innovation output.

On the other hand, one largely unattended research area concerns the way different forms of openness can be combined [13]. This gap in the literature is corroborated by West and Bogers [14, p. 14], who pointed to the dearth of research taking a holistic perspective to study the combination of inbound, outbound, and coupled types. In addition, each type of OI is formed by 
a diverse set of practices, which involve different requirements and have particular advantages for firms. This implies that not all innovating firms necessarily apply all potential OI practices with similar intensity and that they can open their innovation process by combining them in distinct ways. Insights from the configuration approach in the strategic management field can be useful in this respect, as they might help to increase our knowledge of how firms implement their OI innovation strategies. A few papers have adopted a configurational approach to explain how different forms of openness are combined to identify OI patterns in LMT firms (e.g., [10], [15]). Nevertheless, they focus solely on external knowledge sourcing and acquisition, without considering the outbound and coupled OI types. Further research on OI strategies implemented by firms in LMT industries examining the degree to which they apply combinations of inbound, outbound, and coupled OI practices could provide a deeper understanding of the applicability of OI beyond its traditional high-tech focus.

In light of the above, this paper aims to study how LMT firms implement their OI strategy. In order to respond to this question, we focus on the OI practices that help firms purposively manage inflows and outflows of knowledge, since defining various practices for each OI type has been regarded as an effective approach to explain how to do OI [16]. Thus, this paper seeks to identify patterns for OI of LMT firms by adopting a configurational view and exploring how a broad array of OI practices are jointly implemented. In addition, it analyzes whether there are differences in innovation performance among companies that adopt different patterns for their OI strategy by examining innovation results in terms of product, process, and organizational innovation.

This paper contributes to the OI literature by enriching our understanding of OI in the specific context of LMT industries. In particular, we analyze the relevance that inbound, outbound, and coupled OI types have for firms in these settings, and identify OI strategies by exploring how they combine the specific OI practices. Additionally, by relating these OI strategies with different types of innovation performance, we contribute to the existing knowledge on OI. To our knowledge, most research investigating how LMT firms implement OI is of a qualitative nature (e.g., [2], [6], [8], [9], [11], [17]), and the limited studies on larger samples of firms focus on inbound OI (e.g., [10], [15]) or outbound OI (e.g., [18]) within a single industry. The present study also addresses this gap as it is based on a large sample of innovative firms belonging to different LMT sectors, and provides a more complete view of the OI model.

The remainder of the paper is structured as follows. Section II examines the relevant literature and describes the gap in the OI research bridged by our study. The methodology is then presented in Section III, with descriptions of the data and measures for the variables. Following the results and discussion presented in Section IV, Section V concludes this paper.

\section{THEORETICAL BACKGROUND}

\section{A. OI Practices}

OI was recently redefined by Chesbrough and Bogers [12, p. 17] as a "distributed innovation process based on purposively managed knowledge flows across organizational boundaries, using pecuniary and nonpecuniary mechanisms in line with the organization's business model." Management of knowledge flows may involve leveraging external knowledge sources through internal processes, leveraging internal knowledge through external processes, or coupling external knowledge sources, and commercialization activities. Accordingly, three core processes or types of OI have been identified [19], [12]: outside-in (or inbound); inside-out (or outbound); and coupled OI.

When explaining how OI takes place, one approach for identifying OI processes is to define the practices comprising each type of OI [16]. The literature identifies a variety of inbound, outbound, and coupled practices that firms can implement in order to open their innovation process. These practices, in addition to the direction of the knowledge flows, can also be classified in terms of their pecuniary or nonpecuniary nature [13]. Table I presents a characterization of OI practices according to both criteria. The following paragraphs describe the most relevant aspects of each one.

1) Inbound OI Practices: With inbound OI, a company opens up its own innovation processes to many kinds of external inputs and contributions [12]. External knowledge sources help firms to identify potentially valuable opportunities for innovation during the early stages of technology development, while also shaping partners' roles in creating and capturing value in the final stage of commercializing innovation outputs [20]. Hence, the management of knowledge inflows embraces a number of practices aimed at incorporating external knowledge, either through sourcing or through acquiring the external knowledge [13]. Some of these inbound practices may be organized informally and do not involve large investments, but others may require a substantial commitment in terms of financial outlay, formalized contracts, and a structured approach [21].

a) Nonpecuniary inbound practices-Sourcing: Sourcing practices are usually nonpecuniary and include linkages with customers and suppliers, and technological scouting. Opening up the internal innovation process by integrating suppliers' and/or customers' knowledge is not new, as seen in the literature on interfirm collaboration, and particularly on supplier relationship management [19]. OI research considers customers and suppliers to be the key contributors to firms' innovation process [22]-[24]. Customers often become vital stakeholders as a firm's awareness of its customers' needs and expectations grows, and this will have a positive influence on idea generation, development, testing, and market launch [25]. Suppliers can help frame the possibilities for innovation based on the capacities of the materials, equipment, and techniques they provide [23], [24], [26]. Repeated long-term contact with suppliers maximizes use of external resources and makes the new product development process more flexible [27]. Their relevance in the OI context is highlighted by Laursen and Salter [22], whose study of U.K. firms showed that suppliers are considered to be the most important source of innovation.

According to Parida et al. [25, p. 290], "technology scouting represents an internal search or scanning function related to systematically assessing and observing technology trends in order to detect opportunities and encounter threats in a timely 
TABLE I

CHARACTERIZATION OF OI PRACTICES AND MECHANISMS

\begin{tabular}{|c|c|c|}
\hline & Non-pecuniary & Pecuniary \\
\hline Inbound & $\begin{array}{l}\text { SOURCING } \\
\text { - Linkages with customers } \\
\text { - Linkages with suppliers } \\
\text { - Technological scouting }\end{array}$ & $\begin{array}{l}\text { ACQUIRING } \\
\text { Technology and knowledge purchase } \\
\text { - Innovation intermediaries } \\
\text { - Intellectual property in-licensing } \\
\text { - R\&D outsourcing } \\
\text { Research partnerships } \\
\text { - Collaborative arrangements with } \\
\text { universities and research centers } \\
\text { - R\&D cooperation }\end{array}$ \\
\hline Outbound & $\begin{array}{l}\text { REVEALING } \\
\text { - Donation to commons or non- } \\
\text { profits }\end{array}$ & $\begin{array}{l}\text { SELLING } \\
\text { - Intellectual property out-licensing } \\
\text { - External corporate venturing }\end{array}$ \\
\hline Coupled & $\begin{array}{l}\text { NON PECUNIARY COUPLED } \\
\text { - Participation in networks } \\
\text { - Innovation communities } \\
\text { - Regional clusters }\end{array}$ & $\begin{array}{l}\text { PECUNIARY COUPLED } \\
\text { - Sharing facilities }\end{array}$ \\
\hline
\end{tabular}

manner." Advanced scouting mechanisms would therefore help firms identify market opportunities and judiciously decide which innovative product ideas to develop [25]. Thus, organizations wishing to match external knowledge and ideas with their internal core competences should have a strategy in place to optimize investments in the technologies they identify, since this will give them competitive advantage by effectively linking technology intelligence with OI [28].

b) Pecuniary inbound practices-Acquiring: In addition to sourcing, inbound OI can also take the form of acquiring knowledge for the innovation process by purchasing technology through the market place, and through active and deliberate cooperation with other firms and institutions via research partnerships [13], [20], [29]. Technology purchase is typically seen as a form of transactional arrangement undertaken to acquire external knowledge [20]. Firms can purchase technology and knowledge through innovation intermediaries, outsourcing R\&D activities, and in-licensing. Innovation intermediaries bridge the gap between firms looking for solutions to R\&D problems and solvers, either through traditional channels or by operating a virtual community of customers with an interest in a specific product or brand [30]. Using innovation intermediaries may benefit firms by providing advantages, such as integrating customer knowledge, leveraging technical expertise from individuals outside the firm or appraising, and evaluating external technology [31], [32]. When firms outsource R\&D activities, they are buying these services from specialized technical service providers, such as engineering firms and high-tech institutions to acquire external knowledge [21]. Rather than entering into long-term relationships with these $\mathrm{R} \& \mathrm{D}$ suppliers, firms sign temporary contracts for a previously specified purpose, and they can switch suppliers when new or more cost-effective technologies come onto the market [33]. R\&D outsourcing may therefore lead to several potential benefits [34]: Fixed costs may fall, and R\&D time and budgets may be better controlled; quality advantages may result from the contractor's use of specialized resources and know how; and bringing in new research methods and perspectives may foster creativity in internal R\&D. The use of in-licensing to acquire technologies, or the rights to use them, from external organizations reduces R\&D risk, since they are usually at the end of the development process and have good proven performance [35]. Knowledge acquired through in-licensing may therefore enrich or complement the firm's technology portfolio, and also increase the internal resources available for generating new technology [36].

Research partnerships are formal agreements among organizations that wish to collaborate on $R \& D$ activities. These interorganizational collaborations are intended to be less formal than transactional technology purchases [20]. They either involve firms and public research organizations (i.e., universities, research institutes, public research laboratories) or only firms [37]. Collaborative arrangements with universities and research centers, often referred to as industry-sponsored research, help interorganizational relationships over a prolonged period of time and involve individuals and teams from academia and industry working together on specific projects to produce common outputs [37]. When accompanied by public funding opportunities, such cooperation arrangements are increasingly regarded as inexpensive sources of specialist knowledge [38]. These partnerships give firms a better understanding of the mechanisms underlying emerging scientific developments, thus facilitating new breakthrough innovations and products [39]. Research partnerships with other firms, also known as R\&D cooperation, are usually a medium-term arrangement in which partners share common objectives in a project to develop a specific technology [33]. Research collaboration is considered to be a more open 
strategy of knowledge sharing than R\&D outsourcing, and involves more complex and tacit exchange of knowledge. Firms seek to collaborate with competitors to learn more about technological skills that can be difficult, time consuming, and costly to develop internally [27]. Also, firms in other industries may be a valuable source of cross-industry innovation, enabling creative imitation, and transfer of existing solutions across industries to satisfy current market needs [40].

2) Outbound OI Practices: In managing knowledge outflows, organizations must allow unused and under-used ideas and assets to leave the organization so that other businesses can take advantage of them [12]. Outbound OI may also involve a variety of practices demanding different levels of commitment, either in terms of financial resources or the organizational arrangements required. Depending on whether they are pecuniary or nonpecuniary, Dahlander and Gann [13] identify two forms of outbound innovation: Selling and revealing.

a) Nonpecuniary outbound practices-Revealing: Revealing is the nonpecuniary form of outbound OI and concerns the way firms selectively reveal internal resources to the external environment with no immediate financial gain, either by sharing knowledge via donations or as part of a standards setting process, in pursuit of indirect benefits for the firm and having weighed up the commercial pros and cons [13], [41]. The benefits of revealing are related to both marketing and technical aspects, and open up new opportunities to create and capture value as a consequence of increasing interest from other parties [41], [18]. Although revealing might not require high commitment and investments, the challenge lies in choosing which internal resources to reveal to the external environment, since one disadvantage of this practice is that competitors might be in a better position to make use of the technological advance [13]. While some large companies have committees to decide whether to file patents or disclose, smaller companies typically lack the resources to take on this process [13].

b) Pecuniary outbound practices-Selling: Selling refers to how firms commercialize their inventions and technologies through selling or licensing out resources. It enables firms to leverage their R\&D investments more fully by joining forces with actors skilled at bringing inventions onto the market [13]. In this category, practices, such as out-licensing intellectual property (IP) and external corporate venturing may entail substantial efforts and investments [21]. Out-licensing allows the commercialization of unused assets and exploitation of existing technological knowledge outside the firm's boundary when it lacks sufficient market knowledge or other complementary resources to exploit its technologies internally, and other firms with different business models find profitable external paths to the market [21], [42]. Through out-licencing, firms not only generate value from their innovation in the form of fees by engaging in outward technology, but can also expand their technology further and more rapidly to a wider range of markets than they could on their own [43]. Despite the potential benefits of out-licensing, it is a challenging activity for most firms due to its high complexity, as there are significant transaction costs involved in transferring technologies between organizations [13], [44]. Corporate venturing entails the origination, financing, and development of new business ventures [45]. With these types of initiatives, a parent organization draws on internal knowledge to start up new organizations (i.e., it involves spin-off and spin-out processes) and provides support in the form of finance, human capital, legal advice, administrative services, and so on [21]. It allows large consolidated firms to identify and capture the strategic value of emerging technology and entrepreneurial ventures [46], [47]. These tasks are usually performed by venturing units, which help their corporate parents exploit existing assets and competencies [45].

3) Coupled OI Practices: Coupled OI involves combining purposive inflows and outflows of knowledge to collaboratively develop and/or commercialize an innovation [19]. While coupled OI can, in principle, involve any combination of the respective mechanisms for inbound and outbound OI, firms may implement specific mechanisms, all involving complementary partners [12]. These include practices, such as participation in strategic networks, innovation communities, regional innovation clusters, and shared facilities. With the exception of shared facilities, they can essentially be regarded as nonpecuniary, as they exchange knowledge without financial compensation.

a) Nonpecuniary coupled practices: Participation in networks typically involves deep, long-term interaction between parties, usually resulting in an intensive exchange of knowledge and mutual learning. Although networks may evolve into formal collaborative efforts, the fact that they are based on both individual and organizational relationships allows firms to rapidly meet specific knowledge needs without spending huge amounts of time and money [21]. Hence, a network provides informational benefits, is grounded on the informal ties that reflect personal connections between managers and external partners, and is characterized by mutual trust and reciprocity that network members can draw on with fairly unrestricted access [8], [48]. Similarly, the informal nature of innovation communities seems to be especially important in situations with no formal structures for innovation projects or interorganizational cooperation [49]. Innovation communities represent voluntary associations of actors, typically lacking in a priori common organizational affiliation, but united by a shared goal, related to filling a real gap in the innovation process [49], [50]. Some of the benefits of innovation communities include providing access to additional resources and know how, serving as a repository for shared relevant information, and offering mutual support and motivation, although their formation and evolution seems to depend on the specific context and condition of the innovation process [49]. Regional clusters have been defined as "geographical concentrations of interconnected companies and institutions in a particular field" [51]. Active participation in clusters entails different levels of involvement and may sometimes be formalized in highly structured projects, whereas other clusters will be informal and fairly unstructured. The fact that clusters are characterized by active knowledge flows among a diverse set of sources is of great importance in terms of their supporting both formal information exchange and tacit knowledge sharing to facilitate innovation [52]. Therefore, this activity can be very relevant to firms' OI strategies, since benefits arise from localized knowledge spillovers, lower costs of relational collaboration, and greater trust and reciprocity that characterize clusters [53]-[55]. 
TABLE II

OI STUDIES IN LMT INDUSTRIES

\begin{tabular}{lcll}
\hline \multicolumn{1}{c}{ Authors } & Year & \multicolumn{1}{c}{ Industry } & \multicolumn{1}{c}{ Data source } \\
\hline $\begin{array}{l}\text { Chesbrough and Crowther } \\
\text { Lecoq and Demil }\end{array}$ & 2006 & $\begin{array}{l}\text { Non-high-tech } \\
\text { Table top role- } \\
\text { playing game }\end{array}$ & $\begin{array}{l}\text { Interview with managers from 12 firms } \\
\text { Data on 147 firms drawn from } \\
\text { publications and websites }\end{array}$ \\
$\begin{array}{lcll}\text { Sarkar and Costa } \\
\text { Spithoven } \text { et al. }\end{array}$ & 2008 & $\begin{array}{l}\text { Food processing } \\
\text { Traditional sectors }\end{array}$ & $\begin{array}{l}\text { Existing literature on 3 cases } \\
\text { Interviews with CEOs on 12 collective } \\
\text { research centers }\end{array}$ \\
$\begin{array}{l}\text { Chiaroni } \text { et al. } \\
\text { Chiaroni } \text { et al. }\end{array}$ & 2010 & Asset-intensive & $\begin{array}{l}\text { Interview with managers from 4 firms } \\
\text { Garcia Martinez et al. }\end{array}$ \\
Galati et al. & 2011 & Asset-intensive & Interview with manager from 1 firm \\
Dooley and O'Reilly & 2014 & Food and drink & $\begin{array}{l}\text { Data on 284 firms from a survey sent to } \\
\text { R\&D and innovation managers }\end{array}$ \\
& 2016 & Food and drink & $\begin{array}{l}\text { Survey of 47 firms and 2 cases } \\
\text { Interviews with the managing director } \\
\text { and/or founder of 4 firms }\end{array}$ \\
\hline
\end{tabular}

b) Pecuniary coupled practices: Firms can also develop pecuniary coupled practices by participating in initiatives for sharing facilities. This option offers third parties access to a facility without the need for investment, which in turn leads to new business relations and collaborations and stimulates knowledge sharing and competence development. The OI arena is one particular type of shared facilities in an OI context. An OI arena is a platform for joint knowledge creation with partners from industry, society, and academia, with its own vision, strategy, proprietary goals, and physical premises [56], [57]. This type of actor enables OI within a specific field of expertise and sees itself as a key player in that field. Nevertheless, despite its role in fostering the opening of firms' innovation processes and generating knowledge on its own, participation in an OI arena presents firms with a number of challenges related both to the partners' commitment to the work, and to the complexities of managing such an organization [56], [57].

\section{B. OI in Firms Operating in LMT Industries}

OI has traditionally been associated with HT firms, characterized by intensive R\&D activity and high rates of innovation [1], [22]. The higher levels of both R\&D intensity and uncertainty in these industries create stimulating environments for firms to experiment with OI and to share not only knowledge, but also the costs and risks of uncertain innovative projects [58]. Thus, to achieve their outstanding innovation output, HT firms frequently look outside their boundaries for knowledge relevant to their innovation process, since acquiring new technical skills or capabilities from partner firms is one of the most determinant factors in securing competitive advantage [59]. These particular conditions suggest that the OI practices applied in high-tech settings may not be sensible in low-tech industries, as with few or no internal R\&D capabilities, firms in these industries might not work on technological innovations themselves [1]. Nevertheless, as previous research has highlighted, firms in these industries achieve innovations through activities, such as design, the use of advanced machinery, and training [60], [4], and by adapting and integrating outputs from high-tech firms, the relationships between the parties being a central part of their innovation process [60]-[62]. Accordingly, process innovations are the predominant type of innovation in LMT firms, as the basic development is conducted by technology suppliers and they can be carried out relatively smoothly through the integration of the new technology into existing processes, reorganization measures, and employee retraining [3]. In contrast, product innovation is less prevalent in low than in HT contexts [7], [4], and it is primarily customer oriented, incremental, and conservative in nature [6], [63]. This may be because compared with process innovation, product innovation more often requires $R \& D$ activities [61], which LMT firms do not usually have [3]. Since new technologies are not the only way in which firms can develop new offerings and generate competitive advantage and they may reap the benefits of OI from nontechnological factors [1], OI might be an attractive option for innovative firms in LMT industries and OI processes might develop differently in them. Despite the potential interest of examining how OI is implemented in LMT firms, few studies have explicitly focused on OI in such settings (see Table II).

One of the first contributions to explore OI processes outside HT industries was by Chesbrough and Crowther [2]. These authors found that all the firms in their study engaged in some form of acquisition to bring in technology and that only a few had significant outbound OI-through activities, such as IP outlicensing. Lecoq and Demil [18] examined the introduction of an open system in the U.S. tabletop role-playing game industry, demonstrating that such a strategy might be purposefully employed to gain access to a larger installed customer base as a consequence of standardization and development of complementary products compatible with its own products. Sarkar and Costa [11] reviewed the application of the concept in the food processing industry, finding that $\mathrm{OI}$ does take place in a variety of forms, such as technology insourcing, product development outsourcing, and network creation. Spithoven et al. [17] showed that collective research centers could be a potential alternative to help firms in organizing inbound OI in traditional sectors. Chiaroni 
TABLE III

STUDIES ON TYPES OF OI STRATEGY

\begin{tabular}{|c|c|c|c|}
\hline Authors & Industry & OI types & $\begin{array}{c}\text { Key focus } \\
\end{array}$ \\
\hline Bengston et al. [66] & Manufacturing & Inbound & Type of partners' knowledge content \\
\hline Lazzaroti et al. [67] & Manufacturing & Inbound & $\begin{array}{l}\text { Number/type of partners. Number and type } \\
\text { of phases of the innovation funnel }\end{array}$ \\
\hline $\begin{array}{l}\text { Garcia-Martínez et al. } \\
\text { [10] }\end{array}$ & Food and drink & Inbound & Breadth/depth of external knowledge search \\
\hline Galati et al. [15] & Food & Inbound & $\begin{array}{l}\text { Adoption of innovation sources. } \\
\text { Collaboration with innovation partners. } \\
\text { Acquisition of know-how and R\&D. } \\
\text { Adoption of external resources and ideas. }\end{array}$ \\
\hline Lichtenthaler [68] & $\begin{array}{l}\text { Providers of } \\
\text { R\&D services }\end{array}$ & $\begin{array}{l}\text { Inbound } \\
\text { Outbound }\end{array}$ & $\begin{array}{l}\text { Technology acquisition. Technology } \\
\text { exploitation }\end{array}$ \\
\hline $\begin{array}{l}\text { Lichtenthaler and Ernst } \\
\text { [69] }\end{array}$ & Industrial firms & $\begin{array}{l}\text { Inbound } \\
\text { Outbound }\end{array}$ & $\begin{array}{l}\text { Technology acquisition. Technology } \\
\text { exploitation. Technology aggressiveness }\end{array}$ \\
\hline Michelino et al. [70] & $\begin{array}{l}\text { Biotech and } \\
\text { pharmaceutical }\end{array}$ & $\begin{array}{l}\text { Inbound } \\
\text { Outbound }\end{array}$ & $\begin{array}{l}\text { Revenues from OI. Disposals from OI. } \\
\text { Costs from OI. Additions from OI }\end{array}$ \\
\hline Van de Vrande et al. [21] & $\begin{array}{l}\text { Manufacturing } \\
\text { and services }\end{array}$ & $\begin{array}{l}\text { Inbound } \\
\text { Outbound }\end{array}$ & OI practices \\
\hline Schroll and Mild [71] & $\begin{array}{l}\text { Multiple } \\
\text { industries }\end{array}$ & $\begin{array}{l}\text { Inbound } \\
\text { Outbound }\end{array}$ & OI activities \\
\hline $\begin{array}{l}\text { Brunswicker and } \\
\text { Vanhaberveke [65] }\end{array}$ & $\begin{array}{l}\text { Multiple } \\
\text { industries }\end{array}$ & Inbound & External knowledge sources \\
\hline
\end{tabular}

et al. [8], [9] conducted two studies on the process by which firms adapted their systems to the OI paradigm. They found that firms first introduced outside in OI, focusing initially on collaboration with universities and research centers and, in a later stage, relied on gatekeepers for monitoring the development of technologies. They also found that only after improving its competences in knowledge management and IP protection was a firm able to introduce outbound OI. Garcia Martinez et al. [10] examined the inbound OI strategies of firms in the food and drink industry by focusing on external knowledge sources and found that the most important source was suppliers of equipment and technology, followed closely by customers. Galati et al. [15] examined the adoption of external resources and ideas, and collaboration with external actors. Their results found two distinct patterns in firms' OI strategies, which were associated, to a greater extent, with customers and with universities and research centers, respectively. More recently, Dooley and O'Sullivan [6] showed the importance of knowledge from suppliers and customers in small and medium sized enterprises, although firms also had relationships with universities, research labs, and other commercial firms. Their findings also identified that OI was mostly related to process innovations and involved the inward flow of external technology. When it concerned product innovation, informal relationships with customer and suppliers aided the activity, and it was incremental and of a conservative nature.

On the whole, the literature reflects an increase in the knowledge about OI in LMT industries in the last years. It shows that firms mainly apply inbound OI strategies and, in doing so, may apply various pecuniary and nonpecuniary practices. Nevertheless, most research draws on in-depth interviews (e.g., [2], [17]) and case studies (e.g., [6], [8], [9], [11]). Studies based on large samples of firms are limited to the food and drink industry (e.g.,
[10], [15]). Therefore, additional research is required to examine the three types of OI in larger sample settings in order to further our knowledge of how OI is implemented in LMT industries.

\section{Integrated Approaches to Identify OI Strategies}

A configuration has been defined as a number of specific separate attributes that are meaningful when considered together rather than as individual components [64]. The configuration approach suggests that organizations can be best understood as a synthesis of multiple characteristics. Configurations are especially useful when the objective of the research is to determine dominant patterns in organizations [64]. Since openness is not a binary concept - open versus closed — but represents a mixture of external interactions where not all knowledge flows are of equal value to innovating firms [65], it makes sense to explore whether firms follow specific patterns or configurations when adopting OI. A number of studies have attempted to identify patterns by examining how firms combine different aspects of OI in their innovation strategies (see Table III). Most of these studies focus on inbound OI. Specifically, they concentrate on the types of external knowledge firms access (e.g., [66], [65]), the number of partners and phases of the innovation process involved (e.g., [67]), and the breadth and depth of the external knowledge search (e.g., [10]). Some other studies combine inbound and outbound types, although focusing only on pecuniary practices (e.g., [68]-[70]). A third group of studies adopts a broader view, considering a number of inbound and outbound activities, both pecuniary and nonpecuniary (e.g., [21], [71]).

In general terms, these studies define different patterns that distinctively combine the OI elements examined, ranging from a closed strategy at one extreme to an open strategy at the other, 
with some intermediate strategies in between. As some of these authors state (e.g., [21]), the behaviors identified would suggest a sequence in the adoption of OI strategies. Also, the studies coincide in pointing out that firms rarely focus solely on either inbound practices or outbound practices; rather, although inbound methods are adopted more frequently than outbound methods, they tend to combine the two types (e.g., [21], [72], [68], [71]).

Despite their important contributions to the OI literature and management practice by identifying different patterns in firms' OI behaviors, the focus of previous studies is essentially limited to inbound and outbound OI, whereas coupled OI is not explicitly considered. Additionally, to our knowledge, research on LMT industries is limited to knowledge search strategies of firms in the food and beverage industry (e.g., [15], [10]). Hence, there is clearly a need for further research to advance our understanding of how inbound, outbound, and coupled OI practices combine in LMT firms.

\section{MethodOLOGY}

\section{A. Sample}

Data for this research was drawn from a survey addressed to Spanish innovating firms with more than 50 employees in medium-low and low technology industries, according to the OECD classification of manufacturing industries based on technological intensity [73]. The threshold of 50 employees was chosen because smaller companies adopt and apply OI less often than larger firms, especially for activities that require higher formalization and financial investments [21]. We focused on industries with a high proportion of innovating companies, and the following industrial sectors were identified: Food, textile, paper and cardboard, rubber, and plastics, other machinery and equipment, and furniture. The sample size was determined with a confidence level of $95 \%$ and $\mathrm{a} \pm 5 \%$ sampling error and comprised 244 firms. We also followed a stratified sampling process in terms of sectors and size to determine the composition of the sample. The survey was conducted through computer-assisted telephone interviews. Two respondents in each firm-the general manager and the innovation manager-were interviewed using two separate structured questionnaires as a basis. Previously, the questionnaires were pretested with five firms and academics. To ensure that firms were innovating firms, following the Oslo Manual [74], we began the interview with a screening question that asked respondents if their company had developed at least one innovation in the previous three years. Two questionnaires with incomplete answers were eliminated, resulting in a final sample of 242 firms. Table IV shows the population and the final sample composition for the study. The average firm size, measured by number of employees is 230 (s.d. 598.36) and, on average, their R\&D intensity is $3.48 \%$ (s.d. 4.013), measured by the percentage of $R \& D$ expenditure as a share of total sales.

\section{B. Measures}

1) OI Practices: To gather information on OI adoption by firms, we followed a similar approach to that used by Chesbrough and Brunswicker [75] and van den Vrande et al. [21] and
TABLE IV

SAMPLE COMPOSITION

\begin{tabular}{|l|c|}
\hline Sector & Sample \\
\hline Food & 97 \\
\hline Textile & 21 \\
\hline Paper and cardboard & 18 \\
\hline Rubber and plastics & 43 \\
\hline Other machinery and equipment & 49 \\
\hline Furniture & 14 \\
\hline Total & 242 \\
\hline
\end{tabular}

developed a set of questions to measure different OI practices. We identified 15 practices representing inbound, outbound, and coupled OI types (see Table V). Each general manager was asked to rate, on a 7-point scale, the degree of importance of the practices in his/her firm's innovation process during the previous three years $(1=$ not important at all; $7=$ very important $)$ : Customer involvement; supplier involvement; technology scouting; innovation intermediaries: R\&D outsourcing; IP in-licensing; research projects with universities; R\&D cooperation; revealing; IP out-licensing; corporate venturing; innovation networks; innovation communities; participation in regional clusters; facilities sharing.

2) Innovation Output: Innovation output was measured by variables representing product innovation, process innovation, and organizational innovation. In doing so, we adopted questions from The Community Innovation Survey 2010 (CIS), which follows guidelines described in the Oslo Manual [74].

a) Product innovation: We measured product innovation with two types of variables. First, we asked managers if in the previous three years, their firms had introduced 1) a new or significantly improved product onto their market before their competitors; and 2) a new or significantly improved product that was new to the firm (but was already available from their competitors in their market). Each variable was coded with the value 1 when the firm had effectively introduced it and 0 otherwise.

We then followed Laursen and Salter's [22] approach and used a second set of variables to describe product innovation performance indicating the percentage of their firms' total turnover from 1) new or significantly improved products introduced during the previous three years that were new to their market; 2) new or significantly improved products introduced during the three years that were only new to their firm; and 3) products that were unchanged or only marginally modified during the three years.

b) Process innovation: In line with the CIS survey, respondents were asked to indicate whether in the previous three years, the firm had introduced 1) new or significantly improved methods of manufacturing or producing goods or services; (2) new or significantly improved logistics, delivery or distribution methods for its inputs, goods or services; and (3) new or significantly improved supporting activities for its processes. Following previous research [76], we created a dummy variable and assigned the value of 1 if the firm had introduced at least one process innovation of any type and 0 otherwise. 
TABLE V

DESCRIPTIVE ANALYSIS OF OI PRACTICES

\begin{tabular}{|l|c|c|c|c|}
\hline \multicolumn{1}{|c|}{ OI PRACTICE } & Mean & $\begin{array}{c}\text { Std. } \\
\text { deviation }\end{array}$ & $\begin{array}{c}\text { Practice not } \\
\text { important/very } \\
\text { little importance } \\
\text { (\% of firms) }\end{array}$ & $\begin{array}{c}\text { Practice } \\
\text { important/very } \\
\text { important } \\
\text { (\%) of firms) }\end{array}$ \\
\hline Customer involvement & 5.2 & 1.37 & 5.3 & 51.6 \\
\hline Supplier involvement & 4.9 & 1.42 & 6.6 & 41.0 \\
\hline Technology scouting & 3.9 & 1.61 & 21.7 & 11.1 \\
\hline Innovation intermediaries & 3.7 & 1.6 & 22.5 & 8.2 \\
\hline R\&D outsourcing & 4.3 & 1.57 & 14.3 & 24.2 \\
\hline IP in-licensing & 3.5 & 1.88 & 36.5 & 18.4 \\
\hline Research projects with universities & 4.5 & 1.52 & 11.5 & 27.9 \\
\hline R\&D cooperation & 4.1 & 1.45 & 11.9 & 15.2 \\
\hline Revealing & 3.8 & 1.82 & 27.5 & 15.2 \\
\hline IP out-licensing & 2.7 & 1.74 & 55.3 & 7 \\
\hline Corporate venturing & 2.7 & 1.72 & 56.6 & 7 \\
\hline Innovation networks & 4.1 & 1.69 & 24.2 & 23.8 \\
\hline Innovation communities & 3.3 & 1.63 & 35.2 & 9.4 \\
\hline Participation in regional clusters & 3.8 & 1.65 & 23.4 & 16.4 \\
\hline Facilities sharing & 2.8 & 1.62 & 53.3 & 6.6 \\
\hline
\end{tabular}

c) Organizational innovation: Managers were asked to indicate if during the previous three years the company had introduced 1) new business practices for organizing procedures; 2) new methods of organizing work responsibilities and decision making; and 3) new methods of organizing external relations with other firms or public institutions. In line with previous studies [76], [77], the variable was calculated so that each firm received a score of 0 when no organizational innovation was introduced and 1 if the firm had adopted at least one organizational innovation of any type.

\section{RESULTS}

\section{A. Importance of OI Practices in LMT Firms}

Table $\mathrm{V}$ presents the descriptive statistics and the importance of the OI practices in our sample, as expressed by the percentage of firms that consider them important/very important, and those that consider them not important/of very little importance. There is a broad variance in relevance among the inbound practices. The most relevant practices are customers' and suppliers' involvement. Thus, more than $50 \%$ of firms consider participation in activities designed to capture customers' ideas as important or very important; and $41 \%$ of firms see participation in activities aimed at capturing suppliers' ideas as important or very important. These are followed by research projects with universities and research centers (27.9\%) and R\&D subcontracting (24.2\%). Both practices are linked to the search for specific scientific and technical knowledge beyond the industry value chain as a way to complement the firm's knowledge base in particular aspects. In-licensing also provides the firm with specific knowledge, but it is only considered as very important by $18.4 \%$ of firms. Similarly, only a relatively small percentage of firms (15.2\%) consider the benefits of R\&D cooperation to be very important. A low percentage of firms consider it important to systematically assess and observe technological trends (11.1\%). Using intermediaries is not a widespread practice among LMT firms (8.2\%), even though it also provides firms with solutions to specific knowledge needs.

LMT firms consider outbound practices to be less relevant than inbound practices. Revealing is only considered important by $15.2 \%$ of firms. A very low percentage of firms (7\%) considers IP out-licensing and corporate venturing to be very important. These two practices can be regarded as more demanding, since as well as requiring the firm to disclose knowledge they involve a formal agreement between parties and monetary compensation.

Participation in regional networks is the coupled practice firms most value (23.8\%). Participation in innovation clusters reveals that a relatively small group of firms are convinced of the benefits of this practice and regard it as of high importance (16.4\%). The other two coupled practices examined, participation in innovation communities $(9.4 \%)$ and facility sharing $(6.6 \%)$, are barely used by firms.

These results show that, in general terms, adoption of OI by LMT firms is still in its infancy with regard to the inbound, outbound, and coupled practices examined in the study, as, with exception of traditional and well-known practices such as customer and supplier involvement and cooperation with universities, less than $25 \%$ of firms consider most of these practices to be important or very important to their innovation processes.

\section{B. Cluster Analysis}

To examine the adoption of OI among LMT firms in more detail, we searched for different OI strategy patterns. Following 
TABLE VI

CORRELATION MATRIX OF OI PRACTICES

\begin{tabular}{|c|c|c|c|c|c|c|c|c|c|c|c|c|c|c|c|}
\hline & 1 & 2 & 3 & 4 & 5 & 6 & 7 & 8 & 9 & 10 & 11 & 12 & 13 & 14 & 15 \\
\hline $\begin{array}{l}\text { 1. Customer } \\
\text { involvement }\end{array}$ & 1 & & & & & & & & & & & & & & \\
\hline $\begin{array}{l}\text { 2. Supplier } \\
\text { involvement }\end{array}$ & $0.704^{* *}$ & 1 & & & & & & & & & & & & & \\
\hline $\begin{array}{l}\text { 3.Technology } \\
\text { scouting }\end{array}$ & $0.413^{* *}$ & $0.363^{* *}$ & 1 & & & & & & & & & & & & \\
\hline $\begin{array}{l}\text { 4. Innovation } \\
\text { intermediaries }\end{array}$ & $0.265^{* *}$ & $0.297^{* *}$ & $0.583^{* *}$ & 1 & & & & & & & & & & & \\
\hline $\begin{array}{l}\text { 5. R\&D } \\
\text { outsourcing }\end{array}$ & $0.303^{* *}$ & $0.283^{* *}$ & $0.414^{* *}$ & $0.367^{* *}$ & 1 & & & & & & & & & & \\
\hline 6. IP in-licensing & $0.225^{* *}$ & $0.191^{* *}$ & $0.274^{* *}$ & $0.210^{* *}$ & $0.194^{* *}$ & 1 & & & & & & & & & \\
\hline $\begin{array}{l}\text { 7. Research } \\
\text { projects with } \\
\text { universities }\end{array}$ & $0.310^{* *}$ & $0.299^{* *}$ & $0.328^{* *}$ & $0.340^{* *}$ & $0.421^{* *}$ & $0.204^{* *}$ & 1 & & & & & & & & \\
\hline $\begin{array}{l}\text { 8. R\&D } \\
\text { cooperation }\end{array}$ & $0.273^{* *}$ & $0.161^{*}$ & $0.509^{* *}$ & $0.489^{* *}$ & $0.405^{* *}$ & $0.304^{* *}$ & $0.527^{* *}$ & 1 & & & & & & & \\
\hline 9. Revealing & $0.297^{* *}$ & $0.309^{* *}$ & $0.585^{* *}$ & $0.649^{* *}$ & $0.351^{* *}$ & $0.154^{*}$ & $0.288^{* *}$ & $0.419^{* *}$ & 1 & & & & & & \\
\hline $\begin{array}{l}\text { 10. IP out- } \\
\text { licensing }\end{array}$ & $0.160^{*}$ & $0.244^{* *}$ & $0.396^{* *}$ & $0.355^{* *}$ & $0.333^{* *}$ & $0.544^{* *}$ & $0.215^{* *}$ & $0.344^{* *}$ & $0.400^{* *}$ & 1 & & & & & \\
\hline $\begin{array}{l}\text { 11. Corporate } \\
\text { venturing }\end{array}$ & $0.206^{* *}$ & 0.091 & $0.337^{* *}$ & $0.400^{* *}$ & $0.145^{*}$ & $0.323^{* *}$ & 0.116 & $0.284^{* *}$ & $0.300^{* *}$ & $0.318^{* *}$ & 1 & & & & \\
\hline $\begin{array}{l}\text { 12. Innovation } \\
\text { networks }\end{array}$ & $0.337^{* *}$ & $0.295^{* *}$ & $0.405^{* *}$ & $0.509^{* *}$ & $0.268^{* *}$ & $0.240^{* *}$ & $0.306^{* *}$ & $0.405^{* *}$ & $0.420^{* *}$ & $0.404^{* *}$ & $0.294^{* *}$ & 1 & & & \\
\hline $\begin{array}{l}\text { 13. Innovation } \\
\text { communities }\end{array}$ & $0.331^{* *}$ & $0.301^{* *}$ & $0.462^{* *}$ & $0.515^{* *}$ & $0.397^{* *}$ & $0.394^{* *}$ & $0.215^{* *}$ & $0.422^{* *}$ & $0.372^{* *}$ & $0.535^{* *}$ & $0.397^{* *}$ & $0.519^{* *}$ & 1 & & \\
\hline $\begin{array}{l}\text { 14. Participation } \\
\text { in clusters }\end{array}$ & $0.282^{* *}$ & $0.195^{* *}$ & $0.411^{* *}$ & $0.511^{* *}$ & $0.351^{* *}$ & $0.284^{* *}$ & $0.364^{* *}$ & $0.412^{* *}$ & $0.325^{* *}$ & $0.277^{* *}$ & $0.333^{* *}$ & $0.559^{* *}$ & $0.422^{* *}$ & 1 & \\
\hline $\begin{array}{l}\text { 15. Facilities } \\
\text { sharing }\end{array}$ & $0.287^{* *}$ & $0.257^{* *}$ & $0.511^{* *}$ & $0.477^{* *}$ & $0.336^{* *}$ & $0.323^{* *}$ & $0.211^{* *}$ & $0.386^{* *}$ & $0.425^{* *}$ & $0.431^{* *}$ & $0.421^{* *}$ & $0.398^{* *}$ & $0.516^{* *}$ & $0.374^{* *}$ & 1 \\
\hline
\end{tabular}

previous research within the OI literature (e.g., [68] [21], [67]), we performed a cluster analysis and explored the differences between clusters with nonparametric tests. We used the inbound, outbound, and coupled OI practices as an input to perform the analysis. Previously, we carried out a correlation analysis to control for potential high correlation between the variables. Only $14.6 \%$ of significant bivariate correlations (14 out of 96) had a Rho value above 0.5 , indicating that high correlation was not a serious problem (see Table VI).

To identify the number of clusters, we adopted a two-step approach combining a hierarchical approach followed by a nonhierarchical approach [78]-[80]. First, we used a hierarchical procedure with Ward's method based on squared Euclidian distances. Selection of Ward's method was justified by the type of variables used and the fact that there were no outliers [79]. Second, in order to determine the number of clusters, we considered a set of initial solutions ranging between two and five clusters from the hierarchical analysis, as suggested by the dendogram, and performed nonhierarchical cluster analyses to determine the final solution. Thus, using K-means cluster analysis, we generated solutions with two, three, four, and five groups. In addition, we applied the Hubert index test and found that two and three cluster solutions were the most robust. After comparing the two and three cluster solutions, we decided to further explore the three-cluster solution, which provided greater conceptual value. To ensure the reliability of the cluster solution, we followed previous research [65] and chose a random subsample, carried out clustering and compared the results with those based on the overall sample [78], [80]. These results confirmed that the three-cluster solution was stable. Also, we looked for any significant differences between the three OI strategy types in the OI practices. We ran an ANOVA to determine the differences across the groups in those cases in which the assumption of homogeneity of variances held (the Levene statistic was verified). The means differed significantly across all clusters in the three-cluster solution. We also performed the Scheffé post hoc multiple comparison tests. In the cases where the condition of equal variances between the groups was not satisfied, the groups were compared using the Tamhane T2 test, a paired comparison test based on the $t$ statistic. Table VII shows the values associated with the Levene statistic, and the results of the ANOVA and the post hoc tests. The results reveal significant differences among groups for all the practices examined. Table VII also reports the average values of the importance of the OI practices in each of the three groups, showing that inbound practices have the highest importance. Table VIII shows the characteristics of the firms in each group with regard to firm size and R\&D intensity.

All three clusters share the relevance of the inbound practices related to activities aimed to capture customers' and suppliers' ideas. Cluster 1 can be characterized as formed by advanced open innovators, since it is composed of firms in which OI practices have the highest relevance in their innovation process. These are firms that apply a great variety of practices related to the three types of open innovation. Hence, in addition to relying heavily on inbound OI, they use outbound and coupled practices to a greater extent. Specifically, outbound practices 
TABLE VII

Degree of IMPORTANCE OF OI Practices ACross Three Clusters

\begin{tabular}{|c|c|c|c|c|c|c|}
\hline Practice & $\begin{array}{c}\text { Cluster 1 } \\
\text { Advanced OI } \\
(\mathrm{N}=83)\end{array}$ & $\begin{array}{c}\text { Cluster } 2 \\
\text { Intermediate OI } \\
(\mathrm{N}=100)\end{array}$ & $\begin{array}{c}\text { Cluster } \mathbf{3} \\
\text { Incipient } \mathbf{O I} \\
(\mathrm{N}=59)\end{array}$ & Levene & $\boldsymbol{F}$ & $\begin{array}{c}\text { Post-hoc } \\
\text { comparisons }{ }^{1}\end{array}$ \\
\hline \multicolumn{7}{|l|}{ INBOUND } \\
\hline $\begin{array}{l}\text { Customer } \\
\text { involvement }\end{array}$ & 5.87 & 5.20 & 4.34 & $27.900 * *$ & & $\begin{array}{l}2<1 * \\
3<1 * * \\
3<2 * *\end{array}$ \\
\hline Supplier involvement & 5.51 & 4.99 & 4.05 & $10.127 * *$ & & $\begin{array}{l}2<1^{\dagger} \\
3<1 * * \\
3<2 * *\end{array}$ \\
\hline R\&D outsourcing & 5.22 & 4.23 & 3.22 & $15.696^{* *}$ & & $\begin{array}{l}<1 * * \\
3<1 * * \\
3<2 * * \\
\end{array}$ \\
\hline IP in-licensing & 4.87 & 2.87 & 2.69 & $12.836^{* *}$ & & $\begin{array}{l}2<1 * * \\
3<1 * *\end{array}$ \\
\hline $\begin{array}{l}\text { Research projects } \\
\text { with universities }\end{array}$ & 5.17 & 4.44 & 3.59 & $15.586^{* *}$ & & $\begin{array}{l}2<1^{*} \\
3<1 * * \\
3<2^{\dagger}\end{array}$ \\
\hline R\&D Cooperation & 4.95 & 4.17 & 2.83 & $11.348 * *$ & & $\begin{array}{l}2<1 * * * \\
3<1 * * * \\
3<2 * * *\end{array}$ \\
\hline Technology scouting & 4.87 & 4.16 & 2.03 & 1.533 & $104.669 * *$ & $\begin{array}{l}2<1 * * \\
3<1 * * \\
3<2 * *\end{array}$ \\
\hline $\begin{array}{l}\text { Innovation } \\
\text { intermediaries }\end{array}$ & 4.70 & 3.96 & 1.85 & 1.970 & $110.114^{* *}$ & $\begin{array}{l}<<1 * * \\
3<1 * * \\
3<2 * *\end{array}$ \\
\hline \multicolumn{7}{|l|}{ OUTBOUND } \\
\hline Revealing & 4.83 & 4.34 & 1.54 & $4.576^{\dagger}$ & & $\begin{array}{l}2<1^{\dagger} \\
3<1^{* *} \\
3<2 * *\end{array}$ \\
\hline Capital venturing & 3.72 & 2.40 & 1.71 & 2.125 & $33.166^{* *}$ & $\begin{array}{l}<1 * * \\
3<1 * * \\
3<2^{\dagger}\end{array}$ \\
\hline IP out-licensing & 4.16 & 2.36 & 1.17 & $34.768^{* *}$ & & $\begin{array}{l}<1 * \\
3<1 * * \\
3<2 * *\end{array}$ \\
\hline \multicolumn{7}{|l|}{ COUPLED } \\
\hline Innovation networks & 5.42 & 3.96 & 2.49 & $11.874^{* *}$ & & $\begin{array}{l}<1 * * \\
3<1 * * \\
3<2 * *\end{array}$ \\
\hline $\begin{array}{l}\text { Innovation } \\
\text { communities }\end{array}$ & 4.67 & 3.15 & 1.76 & 0.432 & $104.319 * *$ & $\begin{array}{l}<1 * * \\
3<1 * * \\
3<2 * *\end{array}$ \\
\hline Regional clusters & 4.96 & 3.66 & 2.54 & $9.329 * *$ & & $\begin{array}{l}2<1 * * \\
3<1 * * \\
3<2 * *\end{array}$ \\
\hline Facility sharing & 4.04 & 2.51 & 1.49 & $5.906^{*}$ & & $\begin{array}{l}2<1 * * \\
3<1 * * \\
3<2 * *\end{array}$ \\
\hline
\end{tabular}

${ }^{1}$ Scheffé test (Tamhane T2 test under heterogeneity of variances) ${ }^{* *} p<0.01,{ }^{*} p<0.05,{ }^{\dagger} p<0.1$

TABLE VIII

FIRM SIZE AND R\&D INVESTMENT ACROSS OI CLUSTERS (MEAN VALUES AND STD. DV.)

\begin{tabular}{|l|c|c|c|c|c|}
\hline \multicolumn{1}{|c|}{ Variables } & $\begin{array}{c}\text { Cluster 1 } \\
\text { Advanced OI }\end{array}$ & $\begin{array}{c}\text { Cluster 2 } \\
\text { Intermediate OI }\end{array}$ & $\begin{array}{c}\text { Cluster 3 } \\
\text { Incipient OI }\end{array}$ & Levene & $\boldsymbol{F}$ \\
\hline Firm size (employees) & $250.2(477.3)$ & $175.2(162.3)$ & $308.2(1053.4)$ & & 0.97 \\
Firm R\&D (percentage of sales) & $4.18(4.66)$ & $3.28(3.9)$ & $2.85(3.10)$ & 2.12 & \\
\hline
\end{tabular}


TABLE IX

PRODUCT INNOVATION ACROSS OI CLUSTERS (\% OF FIRMS)

\begin{tabular}{|l|c|c|c|c|}
\hline & $\begin{array}{c}\text { Cluster 1 } \\
\text { Advanced OI }\end{array}$ & $\begin{array}{c}\text { Cluster 2 } \\
\text { Intermediate OI }\end{array}$ & $\begin{array}{c}\text { Cluster 3 } \\
\text { Incipient OI }\end{array}$ & $\begin{array}{c}\text { Chi-square } \\
\text { test }\end{array}$ \\
\hline $\begin{array}{l}\text { Introduction of product innovation that } \\
\text { is new to the market }\end{array}$ & 69.9 & 59 & 62.7 & 2.349 \\
\hline $\begin{array}{l}\text { Introduction of product innovation that } \\
\text { is only new to the firm }\end{array}$ & 80.7 & 81 & 79.7 & 0.044 \\
\hline
\end{tabular}

TABLE X

Percentage of Sales Due to Product InNovation Across OI Clusters

\begin{tabular}{|l|c|c|c|c|c|c|}
\hline & $\begin{array}{c}\text { Cluster 1 } \\
\text { Advanced OI }\end{array}$ & $\begin{array}{c}\text { Cluster 2 } \\
\text { Intermediate OI }\end{array}$ & $\begin{array}{c}\text { Cluster 3 } \\
\text { Incipient OI }\end{array}$ & Levene & $\begin{array}{c}\text { Fost-hoc } \\
\text { comparisons }\end{array}$ \\
\hline $\begin{array}{l}\text { Percentage of sales due to } \\
\text { products new to the market }\end{array}$ & 14.34 & 7.35 & 7.20 & $5.094^{*}$ & $\begin{array}{c}2<1^{*} \\
3<1^{*}\end{array}$ \\
\hline $\begin{array}{l}\text { Percentage of sales due to } \\
\text { products only new to the firm }\end{array}$ & 12.61 & 8.95 & 9.48 & 1.155 & 1.518 & \\
\hline $\begin{array}{l}\text { Percentage of sales due to } \\
\text { unchanged or only marginally } \\
\text { modified products }\end{array}$ & 73.05 & 83.70 & 83.32 & $4.573^{\dagger}$ & & $1<2^{\dagger}$ \\
$1<3^{*}$ \\
\hline
\end{tabular}

${ }^{1}$ Scheffé test (Tamhane T2 test under heterogeneity of variances) ${ }^{* *} p<0.01,{ }^{*} p<0.05,{ }^{\dagger} p<0.1$

exemplified by donation to commons and out-licensing are of medium importance (with average scores above 4 on a 7-point scale). Also outstanding in advanced open innovators is the incidence of coupled OI, particularly participation in innovation networks and regional innovation clusters. Cluster 2 is the largest group, comprising $41.3 \%$ of the firms, and can be regarded as containing intermediate open innovators. For most practices, it shows values in between the other two groups. When considering the whole set of practices in this group, relevance of revealing is notable as it has a similar average value to firms in the advanced innovators group. Another notable feature of this group is that IP acquisition achieves the lowest level of importance for inbound practices, which are rated below most coupled practices. Cluster 3, formed by incipient open innovators, is the smallest group, comprising $24.4 \%$ of the firms. As in the other two groups, the OI strategy of firms in this group is strongly defined by the inbound dimension. Nevertheless, the relevance of $\mathrm{OI}$ in the innovation process of firms in this group is lower than the other two clusters. Deeper examination of the importance of practices in the incipient open innovators group shows that the OI strategy of firms is based on traditional, inbound practices, such as involvement of customers and suppliers and, to a lesser extent, on R\&D collaboration with universities and R\&D outsourcing. In-licensing related activities are next in importance, which, despite having a low absolute value, reinforce the inbound approach of this group of firms. Overall, the view on development of OI strategies reflected in the three clusters is similar to that identified in previous research (e.g., [10], [21]).

\section{Innovation Performance Across OI Strategies}

In order to examine if there are differences in innovation performance among firms that adopt a specific pattern for their OI strategy, we conducted comparison tests for the variables representing product, process, and organizational innovation. With regard to introduction of product innovations (see Table IX), $69.9 \%$ of firms in the advanced open innovators group introduced a new or significantly improved product onto its market, a higher percentage than in the intermediate open innovators group (59\% of firms) and incipient open innovators (62.7\%). Concerning the introduction of product innovations new to the firm, our findings show similar percentages of firms in all three clusters, with values around $80 \%$. We conducted Chi square tests to assess differences among groups for both variables and no statistical differences were identified in any case.

We also gathered information on the percentage of sales that was due to product innovations (see Table X). The results show that the average percentage of sales of products new to the market in Cluster 1, formed by advanced open innovators, is $14.34 \%$, and nearly doubles average percentages in Cluster 2, intermediate open innovators $(7.35 \%)$, and Cluster 3 , incipient open innovators $(7.20 \%)$. In this case, post hoc tests confirmed significant statistical differences between mean values in Cluster 1 and the other two clusters. Nevertheless, no differences were found in the percentages of sales due to products only new to the firm. Results for percentage of sales due to unchanged or only marginally modified products corroborate the higher product innovativeness of firms in Cluster 1, since they are significantly lower $(73 \%)$ than those of Cluster $2(83.70 \%)$ and Cluster 3 $(83.32 \%)$.

Results for process innovation and organizational innovation are shown in Table XI. It can be seen that the adoption of process innovations is slightly higher than organizational innovation in all groups. A comparison across clusters shows that both types of innovation were adopted by a higher percentage of firms in Cluster 2 than in the other two groups, although these differences are not statistically significant.

We also studied the association between the types of innovations in each cluster. Results show that the association is significant in two cases: (1) between product innovation new to 
TABLE XI

PROCESS AND ORGANIZATIONAL INNOVATION ACROSS OI CLUSTERS (\% OF FIRMS)

\begin{tabular}{|l|c|c|c|c|}
\hline & $\begin{array}{c}\text { Cluster 1 } \\
\text { Advanced OI }\end{array}$ & $\begin{array}{c}\text { Cluster 2 } \\
\text { Intermediate OI }\end{array}$ & $\begin{array}{c}\text { Cluster 3 } \\
\text { Incipient OI }\end{array}$ & $\begin{array}{c}\text { Chi-square } \\
\text { test }\end{array}$ \\
\hline Process innovation & 79 & 90 & 55 & 1.817 \\
\hline Organizational innovation & 76 & 80 & 50 & 4.800 \\
\hline
\end{tabular}

the market and organization innovation in the advanced open innovators group (Chi-square test $=5.517, \mathrm{p}<0.1)$, and (2) between process innovation and organizational innovation in the intermediate open innovators group (Chi-square test $=11.11$, $p<0.05)$.

\section{CONCLUSION}

\section{A. Theoretical Implications}

Although OI has been analyzed in many diverse contexts, only a few papers have explicitly focused on how firms implement OI practices in LMT settings. In these firms, external knowledge integration and adaptation, and firms' non R\&D capabilities, related to tacit and practical learning, are fundamental inputs in achieving innovation, which explains the preeminence of process over product innovation [3]. A deeper insight on how OI is applied in this type of industry can provide additional validity to the applicability of OI innovation in non HT contexts. In this paper, we addressed this gap by studying the OI strategies followed by firms in LMT industries and examined their adoption in a sample of 242 innovative firms. Our results show how firms implement $\mathrm{OI}$ innovation strategies by combining a wide array of practices related to inbound, outbound, and coupled OI. We also identified specific patterns in the adoption of OI types, finding that firms with a more developed strategy toward OI had a higher performance in terms of product innovation.

Our paper helps to enrich the OI literature in several ways. First, it offers a complete picture of the importance of OI types for firms in LMT industries. Our results show the predominance of inbound innovation over coupled and outbound types in their innovation process. This finding is in line with previous research outside the high-tech context, such as Chesbrough and Crowther [2], who found that while all firms in their study engage in some form of inbound OI, only a few made significant outbound OI efforts. As Chiaroni et al. [9] point out, it may be the case that it is rather difficult to develop the inbound and outbound types of OI at the same time (they did not consider a category for coupled OI), as each OI type requires different capabilities.

This paper shows that although firms in LMT industries are active in implementing inbound open innovation, the relevance of the inbound practices examined varies greatly. In general terms, firms take a traditional approach, mainly focusing on leveraging external knowledge through linkages with closer, more familiar agents, such as customers and suppliers, complemented with scientific partnering. At the other extreme, more novel OI practices, such as scouting and OI intermediaries, are far from familiar to firms. Technology purchase, exemplified by practices, such as R\&D outsourcing, IP acquisition, and innovation intermediaries, is less used than sourcing and research partnership mechanisms. A reason for this relatively lower relevance may be that although acquiring valuable resources has many benefits for an innovation process, expertise is required to search for and evaluate them [13], and firms might not have developed these skills fully. On the whole, our results are in line with recent research on adoption of OI practices (e.g., [75]).

As noted above, our study also revealed that outbound practices are less important than inbound practices in LMT contexts. One possible explanation may be that outbound OI reflects a more advanced stage in OI application and most firms do not feel completely ready to consider them as ways of fully exploiting the advantages of OI. Difficulties in adopting this type of OI are notable and many firms may lack the resources and competences to develop them. Thus, in the case of revealing, even though it might not require a high financial investment, concerns may arise about imitation and other issues related to reduced compatibility, reliability, and so on [41]. Additionally, managing in-licensing contracts can be a complex process due to the low appropriability of knowledge and the difficulty of adequately specifying IP rights [81]. Some challenges of corporate venturing relate to the need for high-level sponsorship to guarantee the necessary long-term engagement [45]. In other words, it seems that only when a firm has gained the relevant experience in knowledge management and IP protection systems, is it able to start using its knowledge proactively [8]. Accordingly, it can be considered that outbound OI strategies are still a long way from full application in LMT industry firms. Again, similar results have been reported in previous research in different settings (e.g., [75], [21], [71]).

The relevance of coupled OI practices is uneven. Participation in networks and regional clusters is notably important. Networks appear to be an attractive option for firms, since they allow them to meet specific needs quickly without investing large amounts of time and money [21], [7]. They can also be put into effect at a personal as well as an organizational level, which suggests that they can be implemented in early stages of the OI journey [9]. At the other extreme, sharing facilities emerges as the least important coupled mechanism. Its pecuniary nature, the challenges associated with firms' commitment and complexity in managing this option, and the fact that it is an inherently location-sensitive activity may help explain this result.

Second, we contribute by identifying common patterns of OI strategies in firms in LMT industries. Since firms can adopt diverse OI practices and each one implies specific demands and benefits for them, they do not use all the practices to the same extent, but rather they implement them with varying levels of intensity and combine them in particular ways. Drawing on the set of OI practices, we identified firms with similar approaches to open innovation. We clustered them into three distinct groups, and found that the only element common to all of them was 
the prevalence of inbound OI practices in firms' innovation processes. The first group is formed of "advanced open innovators," as they consider a wide variety of inbound, outbound, and coupled practices in their innovation process relevant. Firms in the second cluster can be described as "intermediate open innovators": They report above average importance for a variety of inbound practices and revealing, and give medium importance to networking and participation in clusters. The third group is formed of "incipient open innovators," which basically focus their OI efforts on traditional, less demanding, inbound practices. In general terms, even though our analysis is not dynamic, it seems to support the idea suggested by van de Vrande et al. [21] that there is a progression in the adoption of open innovation, hence indirectly reinforcing the sequential approach suggested by Chiaroni et al. [9].

Third, we related the OI patterns with different types of innovation, thus providing additional insights into the contribution of OI strategies to firm innovation performance in LMT industries. Although all the firms in our study were innovative, our results illustrate that specific OI profiles are associated with different innovation results. With regard to the introduction of product innovations, no differences were found among clusters. Nevertheless, the fact that firms in Cluster 1 have higher performance in terms of percentage of sales due to products that are new to the market indicates that a more highly developed OI model is adopted by firms with an effective strategy for product innovation in LMT industries. Product innovation demands the use of new technologies to a far greater extent than process innovations [61] and calls for technology-oriented competencies and possibly specialized R\&D capacities which LMT firms may possess only at a small scale [3]. Hence, a possible explanation for this result may be that the implementation of a more developed OI strategy is a good approach for LMT firms to effectively access these capacities and achieve a higher product innovation performance when considering new-to-the-market innovations.

No differences were found among clusters with regard to process and organizational innovation. The fact that firms introduce process innovations at a similar rate, independently of the OI strategy adopted, confirms that even when the firm does not have its own R\&D competencies, this type of innovation can be carried out relatively smoothly within the context of ongoing operations and innovation efforts in production processes, as the basic development is conducted by technology suppliers [7]. Our results also confirm that organizational innovation is introduced at similar levels in all the OI strategy profiles. This finding could be explained by the fact that organizational innovations are often directly linked to technical innovation processes adopted in LMT contexts [3]. Additionally, our results on the association of organizational innovation and process innovation in firms pertaining to the intermediate open innovator group, and between new-to-the-market product innovation and organizational innovation in the advanced open innovators group might suggest that this type of nontechnical innovation must be taken into account when firms go one step further in the development of their OI innovation strategy. Indeed, as pointed out by Chiaroni et al. [9], the implementation of organizational changes can constitute a starting point of the process of adopting open innovation.

\section{B. Managerial Implications}

Several implications for innovation managers arise from this study. First, managers in LMT industries who are considering adopting an OI approach could extend their traditional inbound activities and explore the possibilities of accessing external knowledge through R\&D outsourcing and cooperation with universities and research centers. Further involvement in OI can be accomplished by reinforcing these traditional and scientific inbound activities and incorporating additional inbound practices, such as IP acquisition, and coupled practices related to participation in networks and innovation clusters as a way to support the implementation of other mechanisms. Despite the advantages of outbound OI, innovation managers should be aware that it also has several difficulties that may limit the extent of a firm's outbound OI activities. In this context, developing capabilities that constitute the basis for proficient internal management of outbound OI is critical to avoid the potential risks and to reap the benefits. The fact that firms with a more developed OI model had a higher innovation performance in terms of sales of products that are new to the market suggests that being more advanced in the implementation of the OI model in LMT industries can be an excellent way to enhance a firm's competitiveness through product innovation. Additionally, the association between the introduction of product innovations that are new to the market and organizational innovations reinforces the role of nontechnological innovations when following this type of OI strategy. Consequently, although the difficulties and costs of implementing an advanced OI strategy should not be overlooked, managers in LMT industries should consider a higher commitment toward OI in their firms and the adoption of new, not previously implemented, OI practices in order to fully reap the benefits of innovation from technological and nontechnological factors.

\section{Limitations and Future Research}

This paper has some limitations. First, although we carried out an extensive literature review to identify a large set of OI practices, we did not obtain information on all the potential practices available to firms (e.g., crowdsourcing, ideas competition, participation in standardization processes, etc.). Gathering data on a broader number of practices would have provided us with a more accurate view of OI implementation in LMT settings. Another limitation stems from the types and measures of innovation to measure innovation performance. Although we followed the Oslo Manual guidelines to measure product, process, and organizational innovation, we did not explore other innovation types, such as incremental or disruptive innovation, which would provide valuable insights in our results. Additionally, although we related OI strategies and firms' innovation performance, we did not analyze the effect of these OI profiles on the attainment of innovation and firm results. Finally, our results insinuated a sequence in the adoption of open innovation, but we did not investigate the transition process that details the steps through which firms open their innovation process [16].

Future work should take into account these points by offering a more complete and detailed description of OI practices and 
mechanisms and by examining the influence of OI strategies on different types of outcomes. Further research should also consider dynamic models and carry out longitudinal analyses to obtain deeper insights into the sequential view of OI and how firms can manage their transition toward OI more effectively.

\section{REFERENCES}

[1] W. Vanhaverbeke, H. Chesbrough, and J. West, "Surfing the new wave of open Innovation research," in Proc. New Frontiers Open Innov., Oxford, U. K., 2014, pp. 281-294.

[2] H. Chesbrough and A. Crowther, "Beyond high tech: Early adopters of open innovation in other industries," $R \& D$ Manage., vol. 36, no. 3, pp. 229236, 2006.

[3] H. Hirsch-Kreinsen, "Patterns of knowledge use in 'low-tech' industries," Prometheus, vol. 33, no. 1, pp. 67-82, 2015.

[4] L. Santamaría, M. J. Nieto, and A. Barge-Gil, "Beyond formal R\&D: Taking advantage of other sources of innovation," Res. Policy, vol. 38, pp. 507-517, 2009.

[5] P. Robertson, K. Smith, and N. van Tunzelmann, "Innovation in low- and medium-technology industries," Res. Policy, vol. 38, no. 3, pp. 441-446, 2009.

[6] L. Dooley and D. O'Sullivan, "Open innovation within the low-technology SME sector," in Researching Open Innovation in SMEs. Singapore: World Scientific, 2018.

[7] Heidenreich, "Innovation in European low- and medium-technology industries," Res. Policy, vol. 38, pp. 483-494, 2009.

[8] D. Chiaroni, V. Chiesa, and F. Frattini, "Unravelling the process from closed to open innovation: Evidence from mature, asset-intensive industries," R\&D Manage., vol. 40, no. 3, pp. 222-245, 2010.

[9] D. Chiaroni, V. Chiesa, and F. Frattini, "The open innovation journey: How firms dynamically implement the emerging innovation management paradigm," Technovation, vol. 31, no. 1, pp. 34-43, 2011.

[10] G. García Martínez, V. Lazzarotti, and R. Manzini, "Open innovation strategies in the food and drink industry: Determinants and impact on innovation performance," Int. J. Technol. Manage., vol. 66, pp. 212-242, 2014.

[11] S. Sarkar and A. Costa, "Dynamics of open innovation in the food industry," Trends Food, Sci. Technol., vol. 19, pp. 574-580, 2008.

[12] H. B. M. Chesbrough, "Explicating open innovation: Clarifying an emerging paradigm for understanding innovation," in New Frontiers in Open Innovation, H. Chesbrough, W. Vanhaverbeke and J. West, Eds., Oxford, U.K.: Oxford Univ. Press, 2014, pp. 3-28.

[13] L. Dahlander and D. Gann, "How open is innovation?," Res. Policy, vol. 39, pp. 699-709, 2010.

[14] J. West and M. Bogers, "Leveraging external sources of innovation: A review of research on open innovation," J. Product Innov. Manage., vol. 31, no. 4, pp. 814-831, 2014

[15] F. Galati, B. Bigliardi, and A. Petroni, "Open innovation in food firms: Implementation strategies, drivers and enabling factors," Int. J. Innov. Manage., vol. 20, p. 1650042, 2016.

[16] E Huizingh, "Open innovation: State-of-the-art and futures perspectives" Technovation, vol. 31, pp. 2-9, 2011.

[17] A. Spithoven, B. Clarysse, and M. Knockaert, "Building absorptive capacity to organise inbound open innovation in traditional industries," Technovation, vol. 30, pp. 130-141, 2011.

[18] X. Lecocq and B. Demil, "Strategizing industry structure: The case of open systems in a low-tech industry," Strategic Manage. J., vol. 27, no. 9, pp. 891-898, 2006.

[19] O. Gassmann and E. Enkel, "Towards a theory of open innovation: Three core process archetypes," in Proc. R\&D Manage. Conf., Lisbon, Portugal, 2004.

[20] F. Huang, J. Rice, P. Galvin, and N. Martin, "Openness and appropriation: Empirical evidence from Australian businesses," IEEE Trans. Eng. Manage., vol. 61, no. 3, pp. 488-498, Aug. 2014.

[21] V. Van de Vrande, P. Jeroen, and W. Vanhaverbeke, "Open innovation in SMEs: Trends, motives and management challenges," Technovation, vol. 29 , no. 6-7, pp. 423-437, 2009.

[22] K. Laursen and A. Salter, "Open for innovation: The role of openness in explaining innovation performance among UK manufacturing firms," Strategic Manage. J., vol. 27, no. 2, pp. 131-150, 2006.
[23] N. Theyel, "Extending open innovation throughout the value chain by small and medium-sized manufacturers," Int. Small Bus. J., vol. 31, no. 3, pp. 256-274, 2013

[24] G. Schuster and A. Brem, "How to benefit from open innovation? An empirical investigation of open innovation, external partnerships and firm capabilities in the automotive industry," Int. J. Technol. Manage., vol. 69, no. 1, pp. 54-76, 2015

[25] V. Parida, M. Westerberg, and J. Frishammar, "Inbound open innovation activities in high-tech SMEs: The impact on innovation performance," $J$. Small Bus. Manage., vol. 50, pp. 283-309, 2012.

[26] M. Inauen, "The Impact of outside-In open innovation on innovation performance," Eur. J. Innov. Manage., vol. 14, no. 4, pp. 496-520, 2011.

[27] J. Chen, Y. Chen, and W. Vanhaverbeke, "The influence of scope, depth, and orientation of external technology sources on the innovative performance of Chinese firms," Technovation, vol. 31, pp. 362-373, 2011.

[28] R. Veugelers, R. Bury, and S. Viaene, "Linking technology intelligence to open innovation," Res. Policy, vol. 77, pp. 335-343, 2010.

[29] V. Van de Vrande, W. Vanhaverbeke, and G. Duysters, "Additivity and complementarity in external technology sourcing: The added value of corporate venture capital investments," IEEE Trans. Eng. Manage., vol. 58, no. 3, pp. 486-496, Aug. 2011.

[30] J. Sieg, M. Wallin, and G. Von Krogh, "Managerial challenges in open innovation: A study of innovation intermediation in the chemical industry," $R \& D$ Manage., vol. 40, no. 3, pp. 281-291, 2010.

[31] J. Howells, "Intermediation and the role of intermediaries in innovation," Res. Policy, vol. 35, no. 5, pp. 715-728, 2006.

[32] G. Verona, E. Prandelli, and M. Sawhney, "Innovation and virtual environments: Towards virtual knowledge brokers,", Org. Stud., vol. 27, no. 6, pp. $755-788,2006$.

[33] E. Gimenez-Fernandez and F. Sandulli, "Modes of inbound knowledge flows: Are cooperation and outsourcing really complementary?," Ind. Innov., vol. 24, no. 8, pp. 795-816, 2017

[34] C. Grimpe and U. Kaiser, "Balancing internal and external knowledge acquisition: The gains and pains from R\&D outsourcing," J. Manage. Stud., vol. 47 , no. 8 , pp. 1483-1509, 2010.

[35] K. Atuahene-Grima, "Inward technology licensing as an alternative to internal R\&D in new product development: A conceptual framework," $J$. Product Innov. Manage., vol. 9, no. 2, pp. 156-167, 1993.

[36] M. F. Bianchi, F. Frattini, J. Lejarraga, and A. Di Minin, "Technology exploitation paths: Combining technological and complementary resources in new product development and licensing," J. Product Innov. Manage., vol. 31, pp. 146-169, 2014

[37] M. Perkmann and K. Walsh, "University-industry relationships and open innovation: Towards a research agenda," Int. J. Manage. Rev., vol. 9, pp. 259-280, 2007.

[38] R. Belderbos, M. Carree, and B. Lokshin, "Cooperative R\&D and firm performance," Res. Policy, vol. 33, no. 10, pp. 1477-1492, 2004.

[39] Y. Chen, W. Vanhverbeke, and J. Du, "The interaction between internal R\&D and different types of external knowledge sourcing: An empirical study of Chinese innovative firms," $R \& D$ Manage., vol. 46, no. 5, pp. 10061023,2016

[40] E. Enkel and O. Gassmann, "Creative imitation: Exploring the case of cross-industry innovation," $R \& D$ Manage., vol. 40, no. 3, pp. 256-270, 2010.

[41] J. Henkel, S. Schöberl, and O. Technische, "The emergence of openness: How and why firms adopt selective revealing in open innovation," Res. Policy, vol. 43, pp. 879-890, 2014.

[42] H. Chesbrough and A. Garman, "How open innovation can help you cope in lean times," Harvard Bus. Rev., vol. 87, pp. 68-76, 2009.

[43] J. Walter, "The influence of firm and industry characteristics on returns from technology licensing deals: Evidence from the US computer and pharmaceutical sectors" $R \& D$ Manage., vol. 42, pp. 435-454, 2012.

[44] U. Sikimic, V. Chiesa, F. Frattini, and V. Scalera, "Investigating the influence of technology inflows on Technology outflows in open innovation processes: A longitudinal analysis," J. Product Innov. Manage., vol. 33, no. 6, pp. 652-669, 2016.

[45] B. Battistini, F. Hacklin, and P. Baschera, "The state of corporate venturing," Res.-Technol. Manage., vol. 56, pp. 31-39, 2013.

[46] G. Dushnitsky and M. J. Lenox, "When do firms undertake R\&D by investing in new ventures?," Strategic Manage. J., vol. 26, no. 10, pp. 947-965, 2005.

[47] J. Napp and T. Minshall, "Corporate venture capital investments for enhancing innovation: Challenges and solutions," Res.-Technol. Manage., vol. 54, no. 2, pp. 27-36, 2011 
[48] X. Zhu, M. Dong, J. Gu, and W. Dou, "How do informal ties drive open innovation? The contingency role of market dynamism," IEEE Trans. Eng. Manage., vol. 64, no. 2, pp. 208-219, May 2017.

[49] K. Fitcher, "Innovation communities: The role of networks of promotors in open innovation," $R \& D$ Manage., vol. 39, no. 4, pp. 357-371, 2009.

[50] J. West and J. Lakhani, "Getting clear about communities in open innovation," Ind. Innov, vol. 15, no. 2, pp. 223-231, 2008.

[51] M. Porter, "Clusters and the new economics of competition," Harvard Bus. Rev., vol. 76, no. 6, pp. 77-90, 1998.

[52] P. I. Bierly and P. Daly, "Alternative knowledge strategies, competitive environment, and organizational performance in small manufacturing firms," Entrepreneurship Theory Pract., vol. 31, no. 4, pp. 493-516, 2007.

[53] P. Cooke, "Regional knowledge capabilities and open innovation: Regional innovation systems and clusters in the asymmetric knowledge economy," in Clusters, Networks \& Innovation, Oxford, U.K.: Oxford Univ. Press, 2005 , pp. 80-112.

[54] C. Simard and J. West, "Knowledge network and geographic locus of innovation.," in Open Innovation: Researching a New Paradigm, H. Chesbrough, W. Vanhaverbeke, and J. West, Eds., Oxford, U.K.: Oxford Univ. Press, 2006.

[55] F. Huang and J. Rice, "Does open innovation work better in regional clusters?," Australas. J. Regional Stud., vol. 19, no. 1, pp. 85-115, 2013.

[56] S. Ollila and M. Elmquist, "Managing open innovation: Exploring challenges at the interfaces of an open innovation arena 20 (4)," Creativity Innov. Manage., vol. 20, no. 4, pp. 273-283, 2011.

[57] A. Yström, H. Aspenberg, and A. Kumlin, "Exploring the creative climate in an open innovation arena: Identifying challenges and possibilities," Eur. J. Innov. Manage., vol. 18, no. 1, pp. 70-85, 2015.

[58] M. Bogers et al., "The open innovation research landscape: Established perspectives and emerging themes across different levels of analysis," Ind. Innov., vol. 24, no. 1, pp. 8-40, 2017.

[59] A. Escribano, A. Fosfuri, and J. Tribó, "Managing external knowledge flows: The moderating role of absorptive capacity," Res. Policy, vol. 38, pp. 96-105, 2009

[60] L. Santamaría, M. J. Nieto, and A. Barge-Gil, "The relevance of different open innovation strategies for R\&D performers," Cuadernos de Economía y Dirección de la Empresa, no. 13, pp. 93-110, 2010.

[61] C. Huang, A. Arundel, and H. Hollanders, "How firms innovate: R\&D, non-R\&D, and technology adaptation," UNU-MERIT, Maastricht, The Netherlands, UNU-Merit working papers no. 027, 2010.

[62] P. Robertson and P. Patel, "New wine in old bottles: Technological diffusion in developed economies," Res. Policy, vol. 36, pp. 708-721, 2007.

[63] H. Hirsch-Kreinsen, “"Low-Tech” innovations," Ind. Innov., vol. 15, no. 1, pp. 19-43, 2008.

[64] D. Miller, "Configurations revisited," Strategic Manage. J., vol. 17, no. 7, pp. 505-512, 1996.

[65] S. Brunswicker and W. Vanhaverbeke, "Open innovation in small and medium-sized enterprises (SMEs): External knowledge sourcing strategies and internal organizational facilitators," J. Small Bus. Manage., vol. 53, no. 4, pp. 1241-1263, 2015.

[66] L. Bengtsson, N. Lakemond, V. Lazzarotti, R. Manzini, and L. Pellegrini, "Open to a select few? Matching partners and knowledge content for open innovation performance," Creativity Innov. Manage., vol. 24, pp. 72-86, 2015.

[67] V. Lazzarotti, R. Manzini, and L. Pellegrini, "Firm-specific factors and the openness degree: A survey of Italian firms," Eur. J. Innov. Manage., vol. 14, no. 4, pp. 412-434, 2011.

[68] U. Lichtenthaler, "Open innovation in practice: An analysis of strategic approaches to technology transactions," IEEE Trans. Eng. Manage., vol. 55, no. 1, pp. 148-157, Feb. 2008.

[69] U. Lichthentaler and H. Ernst, "Opening up the innovation process: The role of technology aggressiveness," $R \& D$ Manage., vol. 39, no. 1, pp. 3854, 2009.

[70] F. Michelino, E. Lamberti, A. Cammarano, and M. Caputo, "Measuring open innovation in the bio-pharmaceutical industry," Creativity Innov. Manage., vol. 24, no. 1, pp. 4-28, 2015.

[71] A. Schroll and A. Mild, "Open innovation modes and the role of internal R\&D," Eur. J. Innov. Manage., vol. 14, no. 4, pp. 475-495, 2011.

[72] C. Verbano, M. Crema, and K. Venturini, "The identification and characterization of open innovation profiles in Italian small and medium-sized enterprises," J. Small Bus. Manage., vol. 53, no. 4, pp. 1052-1075, 2015.

[73] T. Hatzichronoglou, "Revision of the high-technology sector and product classification," OECD, Paris, France, OECD Science, Technology and Industry Working Papers 1997/02, 1997.
[74] OECD/Eurostat, Oslo Manual: Guidelines for Collecting and Interpreting Innovation Data, OECD Publishing, Paris, France, 2005.

[75] H. Chesbrough and S. Brunswicker, "A fad or a phenomenon?: The adoption of open innovation practices in large firms," Res.-Technol. Manage. vol. 57, no. 2, pp. 16-25, 2014.

[76] J. Hervas-Oliver and F. Sempere-Ripoll, "Disentangling the influence of technological process and product innovations," J. Bus. Res., vol. 68, pp. 109-118, 2015.

[77] A. Ganter and A. Hecker, "Deciphering antecedents of organizational innovation," J. Bus. Res., vol. 66, no. 5, pp. 575-584, 2013.

[78] J. Hair, W. Black, B. Babin, and R. Anderson, Multivariate Data Analysis, Upper Saddle River, N. J.: Pearson, 2010.

[79] D. Ketchen and D. Shook, "The application of cluster analysis in strategic management research: An analysis and critique," Strategic Manage. J., vol. 17 , no. 6, pp. 441-458, 1996.

[80] G. Punj and R. D. Stewart, "Cluster analysis in marketing research: Review and suggestions for application," J. Marketing Res., vol. 20, no. 2, pp. 134 $148,1983$.

[81] M. Bianchi and J. Lejarraga, "Learning to license technology: The role of experience and workforce's skills in Spanish manufacturing firms," $R \& D$ Manage., vol. 46, no. S2, pp. 691-705, 2016.

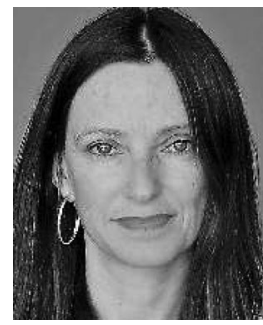

María Luisa Flor received the Ph.D. degree in management from Universitat Jaume I, Castelló, Spain, in 2001.

She is currently an Associate Professor of Management with the Universitat Jaume I, Castelló, Spain. She has authored or coauthored papers in a number of journals, including Creativity and Innovation Management, Research Policy, R\&D Management, Technology Analysis and Strategic Management, Business Process Management Journal, and European Management Journal. Her research interests include innovation management, knowledge management, and open innovation.

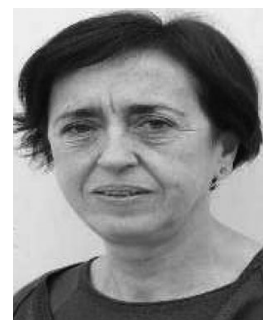

María J. Oltra-Mestre received the Ph.D. degree in agronomic economics and engineering from Universitat Politécnica de València, Spain, in 1993.

She is currently an Associate Professor of Management with the Universitat Jaume I, Castelló, Spain. She has authored or coauthored papers in a number of journals, including Creativity and Innovation Management, Research Policy, $R \& D$ Management, International Journal of Operations and Production Management, Technology Analysis and Strategic Management, Business Process Management Journal, and European Management Journal. Her research interests include innovation and knowledge processes management.

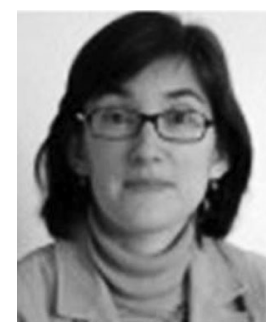

Elena L. Sanjurjo received the Ph.D. degree in applied economics from University of Navarre, Spain, in 1999.

She is currently a part-time Professor of Probability and Statistics at the University of Navarre, Spain. Her research interests include applied statistical methodology and multivariate analysis in the context of open innovation and communication in collaborative innovation. 